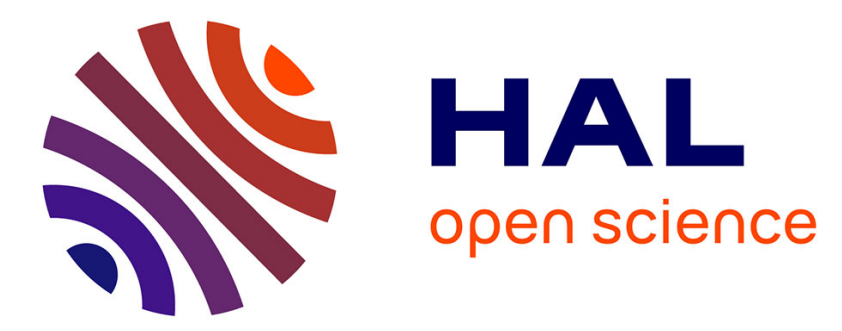

\title{
Non-anthropocentric reasoning in children: its incidence when they are confronted with ecological dilemmas
}

\author{
António Almeida, Clara Maria Vasconcelos, Orlando Strecht-Ribeiro, Joana
}

Torres

\section{- To cite this version:}

António Almeida, Clara Maria Vasconcelos, Orlando Strecht-Ribeiro, Joana Torres. Nonanthropocentric reasoning in children: its incidence when they are confronted with ecological dilemmas. International Journal of Science Education, 2011, pp.1. 10.1080/09500693.2011.608387 . hal00724887

\section{HAL Id: hal-00724887 \\ https://hal.science/hal-00724887}

Submitted on 23 Aug 2012

HAL is a multi-disciplinary open access archive for the deposit and dissemination of scientific research documents, whether they are published or not. The documents may come from teaching and research institutions in France or abroad, or from public or private research centers.
L'archive ouverte pluridisciplinaire HAL, est destinée au dépôt et à la diffusion de documents scientifiques de niveau recherche, publiés ou non, émanant des établissements d'enseignement et de recherche français ou étrangers, des laboratoires publics ou privés. 

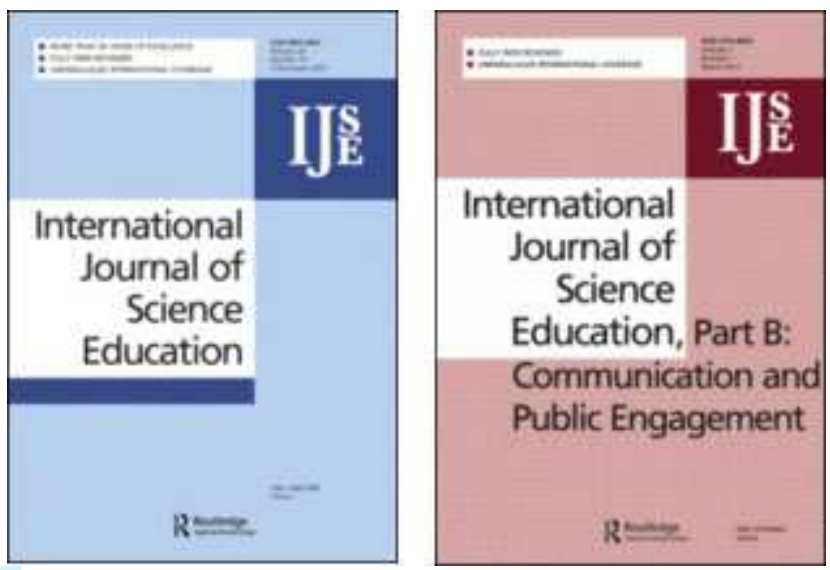

Non-anthropocentric reasoning in children: its incidence when they are confronted with ecological dilemmas

\begin{tabular}{|r|l|}
\hline Journal: & International Journal of Science Education \\
\hline Manuscript ID: & TSED-2011-0030-A.R3 \\
\hline Manuscript Type: & Research Paper \\
\hline Keywords : & ethics, reasoning, primary school \\
\hline Keywords (user): & \\
\hline \multicolumn{2}{|l}{} \\
\hline
\end{tabular}

SCHOLARONE ${ }^{\text {M }}$ Manuscripts 


\section{Non-anthropocentric reasoning in children: its incidence when they are confronted} with ecological dilemmas

\section{Introduction}

General patterns which portray the mode in which cognitive and moral development of the human being is processed, proposed by Jean Piaget (2001) and developed by Laurence Kohlberg (1981), may be encapsulated as follows: each child gradually leaves behind an egocentric way of thinking and acting as he/she acquires the ability to stand outside himself/herself in the course of interactions established with others. This ability leads to a growing concern with the needs of others and an understanding that, in the common interest, it may be necessary to put aside personal whims and desires.

Concern with others is often understood in a restrictive way, since it is confined to human beings. This reflects one of the anthropocentric dimensions about nature and its constituents, which is valued according to its multiple utility for the human being (for recreation, health, aesthetics, resources). However, the perception about the needs of others, or about the conditions necessary for their growth and/or integrity, can be extended to non-human entities and be defended for non-instrumental motives.

The current environmental crisis has no doubt contributed to this perception, due to the awareness of the negative effects of many human interactions with other living creatures and the ecosystems themselves, and increased the theoretical production in the environmental ethics field where distinct philosophical approaches to the conceptualisation of the human-nature relationship emerged. Biocentric theories such as those from Peter Singer (1990), Tom Regan (1983) or Paul Taylor (1989) argue for the intrinsic value of other forms of life, regardless of their relevance to the human species. Singer emphasizes the suffering of animals in animal production and scientific 
investigation. Regan appeals to the rights of animals capable of having desires and aims with a psychophysical identity over time. Taylor prefers not to identify the specificities of complex animals as important and extend the moral consideration to all life.

Also, ecocentric theories such as those of Baird Callicott (1989), Holmes Rolston III (1994) or Arne Naess (1989) endorse a non-instrumental value of the ecosystems and the ecosphere itself, the equilibrium of which can impose limits on particular human activities. Callicott gives importance to the interconnected view between humans and nature of Indian societies. Rolston's belief is centered on the idea that value can exist in nature, independent of human evaluations. Naess posits that Self-realization of human beings is only possible with a strong connection to nature.

The incidence of non anthropocentric reasoning - previous studies Authors working in the field of developmental psychology and more in line with Piaget and Kohlberg have been showing increasing interest in ways of thinking not centred on the human beings, according to age or factors that can accentuate or inhibit them. Studies by Kahn $(1999,2002)$, based on interviews, aimed exactly at confronting the incidence of anthropocentric and biocentric reasoning in children and adolescents in three different regions of the world - Houston (USA), Amazon (Brazil) and Lisbon (Portugal) - when questioned about the seriousness of a variety of environmental problems. The geographic diversification of the samples enabled him to verify whether cultural context is of paramount importance in that reasoning. For instance, one could expect a more biocentric form of reasoning in children from the Amazon, due to their closer and more intense relationship with nature.

The first two studies involved children up to ten and showed a higher frequency of anthropocentric reasoning connected to the dangers occurring from negative action of 
humans upon ecosystems, though some biocentric reasoning could also be detected, albeit at a reduced rate. The Lisbon study involved participants aged 10, 13, 16 and 19, and thereby allowed for a better comparison of frequency of reasoning not centred on the human being according to age (Kahn and Lourenço, 2002). In fact, results showed that biocentric reasoning increased with age, although without majority or exclusiveness and always following an incoherent pattern. As Kahn (2002) explains, with the onset of adulthood, both ways of reasoning coexist and reflect a broader mental organizational structure which sets the frame work for a broader understanding of the inclusion of human beings in nature.

One of the forms that the author considers as biocentric reasoning (and which he deems compositional because it is based on integrity, beauty, harmony or proportion of the whole and the parts), increases considerably with age. Also, due to its holistic nature it seems to represent at least a first approach to ecocentric thinking. It should be said that the late emergence of compositional reasoning is (according to Kahn) due to late comprehension of ecological concepts, which he considers to effectively occur (i.e. occur with obvious effect) in adolescence.

In a nutshell, the three studies carried out in different contexts showed a low frequency of biocentric reasoning in comparative terms, although the choice of topics in which the subjects were questioned influenced the relative frequency of the two kinds of reasoning under discussion. For instance, in one of the studies by Kahn (1997), biocentric reasoning was more frequent when children spoke about the negative effects of an oil spill on marine life than when they talked about the effect of the oil spill on the shore line.

There are several possible explanations for the low frequency of biocentric reasoning, even among the older subjects. Lourenço (2006), one of the researchers in the Lisbon 
study, suggests that such results may be due to a frequent exposure at school to an excessively instrumental view of nature, to the detriment of other perspectives. Even in schools involved in environmental education projects, this perspective prevails over the others and the sustainability discourse is subordinate to emphasis on the welfare of future generations of the human being. The cognitive potentialities of reasoning not centred on the human being for the overall development of young people thus seem to be completely forgotten.

This justification, if accepted as generally true, suggests that the recommendation of Wilson (1993) that one of the main objectives of environmental education is establishing a sense of respect for all living and nonliving elements of the natural world remains to be fulfilled. Furthermore, the appeal by Lijmbach et al. (2002) and Mortari (2004) for the creation (in formal learning contexts) of discussions that allow for the recognition of different ways of understanding the relationship between human beings and nature remains as yet unfulfilled.

However, the school often reflects the same way of thinking as society at large. These ideas establish themselves both implicitly and explicitly in formal learning contexts, but they also determine the process of socialization of children in other contexts. Thus, the low incidence of reasoning not centred on the human being may result from the influence of a prevailing social paradigm of an anthropocentric nature which has become ingrained since the industrial revolution. This paradigm can be characterized as follows: humanity has been freeing itself from many of the constraints to which it has been subject, due to scientific and technological development - this has led to the idea of unlimited progress and a higher consideration of the human being. Nevertheless, this has also led to the present environmental crisis, owing to the several unsustainable ways of exploiting nature that have been implemented. 
However in recent decades, theories not centred on the human being (such as those previously cited) diverge from this paradigm, which has been considered dominant. Franklin (2008) even refers to a recent change of paradigm. And he explains: during part of the $20^{\text {th }}$ century, "animal exploitation, extinction and experimentation were the prices to pay for the great human good" (p.35). However, in the final part of the $20^{\text {th }}$ century, we can see the growth of the politicization of human-animal relations in the Western world with changes in the philosophy of zoos, food diets (showing a decrease in meat consumption) and a new attitude questioning the habit of keeping caged birds or intensive animal production.

A study by Lima and Guerra (2004) establishes a contrastive analysis of two paradigms: the aforementioned Dominant Social Paradigm (anthropocentric) versus the New Ecological Paradigm (non-anthropocentric), and reveals how the Portuguese subscribe to this new paradigm. To this end, the authors applied the NEP (New Environmental Paradigm) scale conceived by Dunlap et al. (2000) that consists of 15 statements about which the participants are asked to express their degree of agreement, often used in research procedures in the US (United States). Results do not support the idea that the Portuguese have a single and exclusive way of connoting the relationships between humans and nature, or that the dominant anthropocentric perspective prevails. In general terms, there was a tendency on the part of the participants to support the new values, and they were critical of the negative impact of the industrial/capitalist society. This tendency was more marked among the younger group (between 15 and 29 years of age) and in the urban population of the Lisbon area, as well as among those with a higher degree of education and higher level of environmental culture (determined by a questionnaire evaluating knowledge on environmental issues). Indeed, the study participants came out strongly in favour of the following statements which are part of 
the aforementioned scale: all species, animal or vegetal, have the same right to exist; human intervention in nature frequently has disastrous consequences; humanity is going too far in an uncontrolled exploitation of the environment and nature. Of course, these results could be deemed incomparable to those from the other previously-mentioned studies due to the older age of the participants. However, a study by Littledyke (2004) with children from the first six years of primary school to elucidate their environmental concerns, concluded that only the concern related to waste had a greater frequency than that related to animals, with the latter taking several forms (exploitation of animals, animals injured/dying from accidents/pollution, animals dying from loss of habitat, threatened/endangered species). Thus, new ways of viewing the relationship between humans and nature seem to be expanding in modern society, and changes in society may radically change the perceptions of people, children naturally included and somewhat contradict Kahn's results.

This discussion is similar to the debate between cognitive and sociocultural perspectives which have dominated recent theorizing about learning and instruction and how the concepts change with development and with the complex process of interaction between individuals in socials and cultural activities (Vosniadou, 2007). However, the study of cognitive strategies in problem solving, learning and thinking abilities used by children, together with the influence of the two perspectives mentioned above, are centred on the children's acquisition of scientific knowledge and changing misconceptions (see Vosniadou, et al., 2005). Also, their implications have to date been less mobilised in the construction of human perspectives with a strong ethical influence.

However, more recent studies revealed that perhaps the incidence of non anthropocentric reasoning can, surprisingly, be a function of more simple factors. A study by Kortenkamp and Moore (2009) specifically revealed the impact of questioning 
the kind of answers from the participants, who changed the incidence of their human or nonhuman-centred reasoning according to the formulation of the questions. Children, when confronted with situations involving animals where human behaviour was considered unfair, considerably increased their biocentric reasoning, even the younger children (average age of ten). Also in a more recent study, Severson and Kahn (2010) revealed similar results, having found a greater incidence of biocentric thinking than that so far presented in developmental literature, in children of the $2^{\text {nd }}$ grade (average $=$ 7.9 years; range $=7.4$ to 8.6 ) and $5^{\text {th }}$ grade (average $=10.6$ years; range $=9.1$ to 11.4 ) When requested to give their opinion on the behaviour of hypothetical aliens that come to earth and commit a series of crimes against the natural inhabitants, including pets, wild animals, orchards and forests, the majority of the children stated their reasons using biocentric reasoning. Only those justifications centred on principles of justice were produced with a greater frequency by the older participants.

The human contact with nature since the Industrial Revolution

Since the Industrial Revolution the forms of interaction between humans and nature have also changed, with implications for the perceptions under discussion. Kellert (1997, 2005) posits that the modern world has followed two trends that complement each other: on the one hand, day-to-day experience, non-planned, in near natural and semi-natural places (direct experience) is disappearing due to contemporary environmental degradation and increasing urbanization; on the other hand, people are increasingly confronted with nature in an unexpected, sporadic and artificial way. This situation has led to a kind of knowledge centred on factual aspects learned in places where nature is managed by humans such as zoos, aquariums and other similar venues (indirect experience), and on more spectacular aspects of the different ecosystems, 
acquired mainly through the media (symbolic experience). According to Kellert (1997, 2005) indirect and symbolic experiences of contact with nature are not an alternative to direct experience because they are excessively structured. Indirect experience lacks the intimacy, challenge, creativity, spontaneity and active participation of direct encounters with nature.

The impact of all of this on the way in which children value nature is difficult to determine because zoos have been abandoning the mere exhibition of animals in small barred cages to dedicate themselves instead to breeding programmes, particularly of endangered species (Franklin, 2008; Maple, 1995). However, this may help to explain the results from a study carried out by Myers et al. (2004) in attempting to understand how 171 interviewed children (aged from 4 to 14) envision the needs of animals, after visiting the Brookfield Zoo in Illinois. Only 10 explicitly referred to freedom as an important need and 16 among the youngest (average age of around 7) even said that their captive animal needed a cage, or to remain captive, which seems to indicate that such places may, in some children produce defective conceptions about the ideal conditions required for the existence and expansion of various species.

Finally (and what is quite apparent in today's society), it bears acknowledging that the number of pets has been increasing tremendously, as a sort of compensation for reduced opportunities for direct contact with nature. And, as Serpell (1996) claims, "pet owners do not value their animals primarily as objects but rather as subjects; as distinctive personalities with whom they have affectionate relationships not dissimilar to the kinds of affectionate relationships they have with close friends and relatives" (p.106). Also, despite being the object of the most diverse forms of anthropomorphization (both by children and adults), they are in fact 'animal ambassadors', mediators establishing a kind of moral link with other types of animals and even nature (Serpell, 2005). 
Therefore, as Melson (2001) states, there is a real possibility that those who care for pets during their childhood may be more sensitive to animal welfare in general and have more ecological concerns, as was revealed in a study with British university students.

\section{The present study}

The purpose of this study was to verify the incidence of anthropocentric, biocentric and ecocentric reasoning in children attending the two final years of the $1^{\text {st }}$ cycle Primary School (ages 8 to 10). This was implemented due to a certain degree of dissatisfaction with the results obtained by Kahn $(1999,2002)$ in his studies, which revealed an extremely low frequency of biocentric reasoning in children of similar ages and even in older groups when questioned about the seriousness of different environmental problems (although this frequency tends to increase with age). However, the question arose as to how adults would respond for instance, when asked why it is negative to pollute a river. Wouldn't the majority give reasons centred on the human being? Doesn't the form in which one sets the question condition the frequency of occurrence of the two main types of reasoning under discussion here?

So, we hypothesed, based on other studies already mentioned, that children can generate a much higher incidence of, at least, biocentric reasoning, depending on the questions posed considering the two following principles: (1) when questions don't appeal directly to an anthropocentric reasoning, because a human threat is evident; (2) when the dilemmas proposed involved animals, and human attitude is considered too egotistical. We also hypothesed that several independent variables such as school year (related to age), gender (in this case, girls) and contact with more biologically complex pets can interfere positively in the incidence of non-anthropocentric reasoning (see statistical data treatment for further details). 


\section{Participants}

This study involved a sample of 123 white Portuguese children (61 boys and 62 girls), aged between 8 and 10 (average 8.52 and $\sigma=0.548)$, attending the $3^{\text {rd }}(67-54.4 \%$ ) and $4^{\text {th }}(56-45.5 \%)$ years in 3 primary schools from the Lisbon area. These schools are attended by middle- and upper middle-class children and 69 (56\%) of them said they had pets at home: 47 owned at least one mammal (greater numbers of dogs and cats than hamsters and rabbits). Other students also referred to non-mammals (birds, tortoises and fish).

These children were chosen because they were pupils of teachers who are usually involved in initial training courses for new primary teachers and were recommended by the coordinator of one of these courses as being particularly receptive to educational research. All teachers had followed their pupils since the first school year and were not involved in projects related to animal welfare or animal rights. In addition, they had never explored the didactic or relational potentialities of including animals in their classrooms.

\section{Procedure}

The children were interviewed about a few ecological dilemmas and questions centred on animals, following written consent from all respective parents in a document where the research study was explained along general lines. The objectives of the interview were also explained to children in class. It was made clear that there would be no right answers but that it would be important to hear their opinions about certain nature subjects. The importance of recording the interviews to help remember what they had said was also explained. 
All interviews took place in the first ten days of October 2009 in a quiet room as near to each classroom as possible. Each child was interviewed alone and would then return to class and call the next. Teachers were asked to discourage conversation in class between already interviewed children and those still waiting. The interviews were conducted in Portuguese and lasted for 15 minutes, which was considered an appropriate length for attention and involvement in children of these ages. To guarantee consistency across all interviews and increase the validity of the data, all respective interviews were conducted by the same interviewer, following the same interview schedule and keeping the same emphasis on the formulation of questions and acceptance of answers.

An interviewing style based on a friendly manner created a relaxed atmosphere and the use of appropriate language matched to the age and ability of primary students was considered to both ensure good communication and encourage the children to express their own views. With a view to obtaining a better understanding of children's ideas, clarification or elaboration was sometimes requested. To assess the convictions of the children about a certain problem or dilemma, a counterargument would be posed. The interviews were audio taped for a better transcription of children's ideas.

Interview questions

We applied a structured interview with open questions since we thought this would be the best way to obtain a spontaneous ethical reasoning. The questions used and their nature are shown in the following table.

\section{Table 1 - Interview questions and their nature}

(insert table 1) 
The questions chosen served to: (1) verify the incidence of non-anthropocentric reasoning in children using one ecological dilemma to relate to a real scenario and two ecological dilemmas in relation to a hypothetical scenario, and; (2) establish those places they visited which permitted contact with animals and whether they have pets, using direct questions to know experiential aspects of the children's life. All questions were written by the research team and selected from a list formulated in a group creative process. The ecological dilemmas in particular were chosen for the following reasons: the principal reason was based in factual information in Kurlansky's (1999) book $A$ Biography of the Fish that Changed the World and was considered a very conflicting situation due the weight of codfish in the Portuguese diet. The other two dilemmas, which were very similar, served to test hypothetical differences in children's answers, considering two mammals of different size and characteristics.

Having constructed the interview, it was then essential to pilot it. Six children of similar age were asked to answer the questions to detect any language limitations or other unforeseen difficulties. The above-mentioned teachers were also asked to read the questions so that they could verify the appropriacy of language to their pupils. During the pilot session no problems were found. However, some of the sample children could not remember any places with animals they had visited or, if so, the names of those places. Consequently, some information was lost here.

The involvement of children in the interview was very good: all were interested in answering and were uninhibited. Kahn (1999) considers that such aspects increase confidence in the data gained and contribute to the validity of the answers.

Scoring 
Answers were coded in a similar way to the studies by Kahn (1999) but with some modifications. If the answer was centred on any kind of benefit for the human being in general or for the child in particular, it would be classified as anthropocentric. This can be done by appealing to an economic value of nature but also to a physical, psychological, educational or aesthetic value, in contributing to personal or societal welfare. If the reasoning was centred on the interests and needs of other living beings, independently of human interests, it would be classified as biocentric. This can be done by appealing to rights and respect to animals, using a kind of isomorphic thought between determining what is right for humans should also be right for other biological entities or criticizing human behaviour as selfish and even suggesting a change in human behaviour.

In cases where answers appealed for holistic relationships between different natural entities, appealing to a system of interconnectedness, dependencies and harmony and revealing nature working as a whole (compositional thought), it would be classified as ecocentric. If more than one type of reasoning was present (for statistical treatment only), we considered that which revealed a less human-centred perspective of nature, thereby assuming a hierarchy between these three different types of reasoning (from anthropocentric to ecocentric reasoning).

\section{Validity and Reliability}

The content validity of the interview was guaranteed in order to subsequently permit appropriate interpretation of scores. In this study, the team choose a content validity determined by the judgment of three experts. The experts carefully reviewed process used to the interview questions and made judgment about how well the questions represented the intended content area. 
To guarantee internal consistency of the codification process, the different answers were independently analysed by each team member. The answers which were codified differently were submitted for team discussion so that a final consensus could be reached.

In the process of data analysis, relative frequencies of the different types of answers were obtained. Some examples of the answers provided by the children are also included for a better understanding of their codification. Some of these transcriptions were subject to a degree of linguistic correction. Seidman's (1998) recommendation was thus followed as he considers that some corrections are justified in order to preserve the dignity of the participant in the written presentation of their oral discourse.

A researcher outside the research team scored the same data, after reading some introductory ideas about anthropocentric, biocentric and ecocentric perspectives. Agreement with the scoring from the research team was total with the exception of one of the reasons given by children for preferring, liking or disliking the places where they met animals. The reason "because it is possible to watch aspects of their behaviour" was considered anthropocentric by revealing a scientific interest about the animals (see discussion section).

Statistical data treatment

For data analysis, descriptive statistics were used to treat data for scoring the frequencies of children's answers after codification. Inferential statistics, namely the SPSS (Statistical Package for Social Sciences) was also used to attempt to establish the influence of a number of independent variables on the incidence of the different types of reasoning under discussion. These variables, as well as the justification for their choice, were as follows: 
-School year of the children - many teachers (based on their experience) believe that pupils make significant cognitive progress between the $3^{\text {rd }}$ and $4^{\text {th }}$ years by becoming more efficient in the use of certain competences. As the children interviewed belonged to the above-mentioned two school years, some differences might have occurred in the two groups.

-Gender - several studies have shown that females are more concerned with issues related to animal welfare and rights, and become more involved in pressure groups fighting for these same causes (Paul, 2005). Although all participants were children, this study attempted to differentiate answers by gender.

-Contact of the children with pets - considering the aforementioned research studies which claim that there is a positive effect of owning pets on the recognition of animal welfare and even on the interest of nature preservation, an attempt was also made to identify possible differences in children's thoughts caused by this variable. Two further groups were created with (1) children who had mammal pets and (2) those who did not. The greater complexity of these animals permitted richer and more diverse kinds of interactions with humans and might reinforce the above-mentioned positive effect. -School of origin - the children attended three different schools. Although none of the teachers were involved in projects related to animal welfare and no specific activities were conducted in the three schools around this topic, learning contexts remain diverse. An attempt was made to try to identify alterations in the type of reasoning caused by this variable.

\section{Results Analysis}

The results obtained from the interview questions are shown as follows, except for the question on pets, which served as an element for sample characterization. As far as the 
places where children said they had seen animals, and their preferences for certain places, the respective results are systematized in Table 2 .

\section{Table 2 - Places where children said they had seen animals and their preferences} (insert table 2)

It is important to note that several children mentioned multiple places where they had seen animals, which explains why the sum of the frequencies for each place is higher than the number of children interviewed. Some children would also provide a noncoded answer due to its vagueness (for instance, in Spain) or to absurdity (for example, in a submarine). Thematic animal parks are prominent in the list (mentioned by 75 children) as is the case of zoos, other parks housing animals with some species in a semi-captivity situation, as in Badoka Park (an open park near Lisbon with savannah animals) as well as oceanariums of the kind. Urban spaces (referred to by 49 children) and rural spaces (25 children) come next in the rank. These three kinds of spaces represent $70 \%$ of those mentioned and refer to places where animals are held in captivity or semi-captivity. On the contrary, seeing animals in natural spaces was mentioned only by 37 children (30\%).

As for the preference of those interviewed for each of these places, 56 children mentioned only one place, which made a choice impossible, or did not show any clear preference. Of the others (63), the majority preferred places where animals were in captivity or semi-captivity which reflects the incidence given to the previous answer. In such places, 31 children chose thematic places with animals, with zoos being their favourite. Also according to the relative frequencies obtained for the previous question, only 15 children preferred to natural spaces. 
Table 3. Reasons given by children for preferring, liking or disliking the places they mentioned

(insert table 3)

Anthropocentric reasons are represented to a greater extent, with numerous references to the fact that the animals were attractive for different reasons (32), the number of animals that can be observed and/or that are unfamiliar (24) and the possibility of contact and interaction (15). Other reasons (though to a smaller extent), were interesting because of the ideas they express and for the formulation of the answers. This group contains the answers given by two children on how much fun they had with establishing animal contact. One child replied: 'I enjoyed watching the dolphins jump. I like to watch the animals because they amuse children'. Some answers provided more than one anthropocentric reason simultaneously. 'I enjoyed seeing them most in the zoo because there I can find animals I like and there are animal shows'.

Despite their low frequency, biocentric reasons had some weight, emphasising the fact that the animals were free and/or in their habitat. For example: 'I preferred to see them 
in the forest because they are in the open air and immersed in nature and that's the place where they should be'.

The last biocentric reason, 'because it is possible to watch aspects of their behaviour', was classified in this category with certain reservations, also considering the opinion of the researcher outside the research team. In fact, the observation of behavioural aspects may show a scientific interest in relation to animals but it may also be of interest in the characteristics of other beings, a recognition of their specificities. In any case, if this sort of answer is not considered as biocentric, the total number in this category will decrease further, emphasising its low frequency.

The answers to the question 'Do you think they liked to be where they were?' covered a broader span of situations: 67 children said 'Yes' (54.5\%); 24 said 'No' (19.5\%); 13 said 'More or less' (10.6\%); 13 said 'Yes and No' (10.6\%); 'Yes and More or less', 1 $(0.8 \%)$; 'No and More or less', $1(0.8 \%)$. The last three types of answer responses show that some children mentioned more than one place, having evaluated them differently and mentioned more than a single reason. Only four children failed to answer this question.

As for the reasons presented, their nature shows an almost total inversion of the type of answer given to the previous question, now clearly non-centred on the human being, as can be seen in Table 4 .

Table 4 -Reasons given by children when evaluating if animals liked or did not like to be where they saw them

(insert table 4) 
The biocentric reasons were primarily of two types: references to favourable conditions for development of the animals and to manifestations of welfare. Both types of references are even made to places where animals are held in captivity and correspond to a very dissimilar evaluation of those places. Some answers given about zoos are a clear example of this. For one child, "animals enjoy being in the zoo because they are well fed and have large open spaces". Another one says, "I think they like it. It's their home". On the contrary, another child answered, "No, because the zoo is a place with small spaces and the keepers who work there don't feed the animals with food they like. They always give them the same thing to eat". On the subject of zoos, yet another child says, "In the zoo some animals are sad because they were caught only to be on show, and get scared seeing many people around them". Regarding zoos, some examples of anthropocentric reasoning were also produced. A child confirming anthropomorphism processes stated, "Yes, because they are being watched and also because some people feed them".

These anthropomorphism processes are also revealed when a child says, "I think some animals like it because they are on the verge of extinction and they know that they are protected there", assuming that animals possess a perception of the predicament in which their species finds itself.

Though they appear with low frequency, the answers that show some doubts about the fact that animals can feel secure in a natural environment are equally interesting. "Animals feel well in the sea, except for fish, which are afraid of being caught by fisherman"; or "In the forests it is complicated. Hunters go there and then kill them. But in the zoo, lots of people visit them and they like it and feel happy".

The results of the analysis of the responses to the first ecological dilemma, dealing with a real scenario, will now be considered. The great majority of children, $102(83 \%)$, 
considered that the action was negative, $9(7 \%)$ considered it positive, $10(8 \%)$ evaluated it both as negative and positive and $2(2 \%)$ did not answer. Reasons given are shown in Table 5, grouped according to the discussed perspectives (anthropocentrism, biocentrism and ecocentrism). Some children justify their answer with more than one reason from the same perspective, while others use reasons from different perspectives.

\section{Table 5 - Reasons for agreeing or disagreeing with the slaughter of seals, as described in the real dilemma presented}

(insert table 5)

Biocentric reasons were clearly in the majority, and among these is the idea that seals are living creatures and deserve to live (65 answers). A good example of this is expressed in the following: "They did wrong because they shouldn't kill. They were bad to the seals. It would be the same if they had killed us". Also, a large number answered that seals have the right to eat and that we should not only think about ourselves. "They did wrong. Maybe seals don't like other kinds of food, or can't find another one they like as much, but we have different kinds of food: cereals, meat and all those things".

Only six children revealed anthropocentric reasoning and three emphasized the idea that seals are good and friendly and produce public displays. It is important to note that ten children produced ecocentric reasoning and five argued that seals are part of nature, which projects an idea of nature being a complex network of relationships which depends on the presence of all elements to work well. And, as one child states, "Nature is exactly like that. Animals eat each other to survive".

Concerning the solutions suggested to solve this dilemma (see Table 6), it should be noted that they were only asked of those children who had somehow disagreed with the original solution provided. Among those who disagreed, 48 did not come up with any 
alternative solutions. The others proposed anthropocentric and biocentric reasons at an almost identical frequency (39 and 33, respectively). Two children suggested two biocentric solutions each and another two suggested a solution of each type.

\section{Table 6 - Alternative solutions to the slaughtering of seals suggested by children} (insert table 6)

One should note here that anthropocentric solutions aim in different ways to transform the nature of seals, highlighting once again anthropomorphic thinking. Note for instance, how five children considered it possible to change the diet of seals in the same way as it is possible to do so with humans. "We could start feeding them with other kinds of fish. Fish they could eat and we wouldn't". Or, "I would feed them with sardines. They would get used to it. That's how they feed them in the zoo and we would keep cod for us". Of the same type were the unrealistic solutions that follow, though the child that produced the third statement is perfectly aware of its impossibility. "I would build a huge swimming-pool where I would put all the seals and then would fish the cod"; "One could put the seals into oceanariums and fish the cod"; "It is complicated. Only if we could build a wall in the sea and put the seals on one side, but that's impossible".

Biocentric solutions call for the need to change human behaviour. Some examples include: 'We could fish less cod and eat less too. And we could eat other kinds of fish'. Or, in a more radical way: 'Everybody could become vegetarians'. Some conciliating solutions were also suggested: to share cod with the seals (10) and to increase the reproduction of $\operatorname{cod}(2)$.

Concerning the hypothetical dilemmas, data will be analysed simultaneously as far as possible, with the aim to verify possible differences occurring in the treatment of similar 
situations with different animals. Children's appreciation of both dilemmas was similar and only three children failed to comment on the dilemma about the hedgehog. Concerning this problem, $98(80 \%)$ children considered it a bad decision, and this number rose to $105(85 \%)$ with the fox dilemma. Only $17(14 \%)$ children considered it to be a good decision in the first dilemma and $14(11 \%)$ in the second. Two children said it had been a good and bad decision at the same time in the first dilemma, and three in the second. Finally, three revealed some indecision in the first dilemma and only one in the second. The justifications found for their agreement or disagreement are presented in Table 7 and have been coded according to the perspectives under analysis. Some children also gave more than one reason.

\section{Table 7 - Reasons for agreeing or disagreeing with the action of capturing a hedgehog and a young fox and putting them in a backyard in an urban environment}

(insert table 7)

It is interesting to note that the majority of reasons were of a biocentric type and most were linked to disagreement with the action of capturing the animals. Nevertheless, the fact that the dilemmas dealt with animals of different size and characteristics and that in the case of the fox a young animal was involved, led to a dissimilar frequency when compared to the reasons given. Therefore, from all the reasons presented in Table 7 the following should be given precedence. Being separated from the mother/family was mentioned by 50 children as a reason to disagree with the action of capturing the young fox and only by 12 in the case of the hedgehog. Similar reasons led the children to agree with the action, believing in this case that the young animal had been abandoned. 'They 
did the right thing to take it because the young animal was alone. They could look after it and then release it. Unless the animal would like to stay'.

The idea that both are wild animals living in the woods and therefore should not be taken to a backyard appears with a high frequency (60 and 29 answers, respectively). However, the smaller size of the hedgehog led six children to agree with the stated action, on the assumption that the backyard would certainly satisfy their needs for space and food. One child expressed her understanding of the different needs of the two animals very well: 'They did wrong because foxes need to hunt and to learn on their own. They run a lot and need the woods. The hedgehog is different because it is small'. Anthropocentric reasons generated the most curious answers because of the ideas they express. An example of this is the fact that 25 children were apprehensive of the possibility of the fox attacking people or wrecking things. 'They did wrong because it will grow up and could then kill people. Foxes are carnivorous'; 'The fox would kill them when it became an adult animal. Foxes are dangerous and cunning'; 'Everybody knows that foxes are naughty: they can go into the house, ruin things and eat all the food'.

In the case of the hedgehog, its prickly aspect impressed six children. Two examples here are relevant: 'They did wrong because they could prick themselves. If they had a baby, the baby could touch it and get pricked'; 'If someone appeared, they could get pricked with its spines'.

It is also important to emphasize that for some children, agreeing with the actions presented in both dilemmas is induced by the belief that the backyard is safer than the woods for both animals. In the case of the hedgehog: 'They did well, because other animals could attack it. It is more protected in the backyard, if they haven't got a dog'. 
In the case of the fox: 'Cheetahs, for example, chase their prey in Africa. Some animals chase foxes too, so there they are protected'.

Finally, we wanted to verify if the incidence of anthropocentric, biocentric and ecocentric thinking (the latter inexistent in the majority of answers) varied according to gender, contact with complex animals (mammals), school origin of the children and school year (aspect related to their age). Results obtained with the questions capable of generating the different types of thinking were analysed according to the different variables. We used the chi-squared test ( $\chi^{2}$ - non-parametric statistics) to test the homogeneity between groups with regard to the incidence of the discussed perspectives, while the level of significance used for the tests was always for values of $p<0.05$ (Table 8).

Table 8 - Level of significance obtained after application of the chi-squared test $(\chi 2)$ to each of the questions capable of generating anthropocentric and nonanthropocentric thinking according to the independent variables gender, school year of the children, contact with animals and school origin

(insert table 8)

We followed the recommendation of Conover (1999) who considers that this test remains valid even for very low rates of expected frequency, provided they do not fall below 1 - even if in some cases, the applicability of the test was verified and in those cases, only a discussion of frequencies was possible. We did not found any differences concerning gender, direct contact with mammals and school origin. In the last case, this confirmation was considered important because it supports a certain degree of sample homogeneity. Considering the school year of the children, the results proved interesting for a couple of reasons. In those questions in which the generation of biocentric thinking 
is supposedly easier (as it is the case with that asking the children to evaluate the living conditions of the animals in those places where they saw them and with the two hypothetical dilemmas involving the hedgehog and the fox), no significant differences were found between the two groups $\left(3^{\text {rd }}\right.$ and $4^{\text {th }}$ school years respectively). For those questions in which the generation of biocentric reasoning is supposedly more difficult (as is the case of that directly appealing to the self and asking for an alternative solution for the real codfish dilemma) the older children attending the $4^{\text {th }}$ year, revealed a greater incidence of this type of reasoning. This fact seems to support the previously referred view held by $1^{\text {st }}$ cycle teachers on the presence of a greater development of children in this school year, thereby confirming the possibility of a higher incidence of biocentric thinking evolving with maturity.

\section{Conclusions}

The findings from this study confirm the hypothesis that young children can generate a much higher biocentric reasoning than that shown in the main studies by Kahn (1999, 2002), as previously mentioned. Our findings also confirm that school year (related to age and cognitive development) can interfere positively in the incidence of a nonanthropocentric reasoning but not gender and contact with more biologically complex pets. These findings support more recent aforementioned research to the effect that the incidence of biocentric reasoning could depend on the way situations were posed for children. Therefore, the results may be interpreted as occurring for two reasons: on the one hand, the focus of the questions seems to condition this incidence strongly. We can see how the majority of the children interviewed (having indicated places where they had observed animals) responded in an anthropocentric manner when expressing their preference for those places, but in an almost exclusively biocentric manner when they 
evaluated the same places from the perspective of animal welfare. On the other hand, when confronted with hypothetical or real dilemmas involving unpleasant situations for the animals, in which human action is considered unfair or egotistical, the majority of their answers were equally biocentric. A clear example of this is the codfish dilemma, portraying a merciless kind of human action, motivated by commercial reasons. However, the prevailing contact of children with spaces where nature is managed by man, to the detriment of natural spaces, does not seem to decrease the frequency of biocentric reasoning although some younger children believe that these places are the natural habitat of certain animals. This could be interpreted as a potential source of concern, and the importance of earlier contact of children with natural places, to augment a better understanding of the needs of other living beings.

Despite the higher frequency of biocentric reasoning, it is important to mention two situations in which a lower frequency was obtained. The first concerns the alternative solutions given by the children to the slaughtering of seals as a potential solution to the codfish problem. Here, the number of anthropocentric solutions was slightly higher than that of biocentric solutions, which implies a certain degree of agreement with the described human action, the continuity of cod fishing, if done less intensively. For more than half the children who presented an alternative solution, a lower impact would imply uncovering strategies to separate seals from codfish or changing their diet and not finding solutions aimed at changing human behaviour. This result might imply that, with the concrete need to act to solve certain problems, the operationalization of biocentric reasoning could lose some ground. Still, since statistically significant differences were found between the $3^{\text {rd }}$ and $4^{\text {th }}$ year children for this dilemma, we can assume that in conceptually more demanding questions and the incidence of biocentric reasoning will partially depend on a greater cognitive maturity. 
The second situation (though less significant in numerical terms) relates to the fact that almost one sixth (1/6) of the children in the sample disagreed with moving the young fox to a backyard because of the danger this animal would represent to humans when it became an adult.

The reference to the danger of foxes to humans is certainly disproportionate and may have been caused by the influence of stories and myths created about a number of animals, often determining their preservation negatively. However, this seems to indicate that the frequency of biocentric thinking in children can be influenced by the type of animals present in certain problematic situations (dilemmas). The evaluation of their danger (real or hypothetical) for humans seems to lead to a decrease in this kind of thinking and other factors such as empathy, experience and scientific knowledge are also expected to influence a higher frequency.

Mechanisms of hierarchizing the species are thus generated which do not always follow plausible criteria. This result is unsurprising if we consider certain movements occurring in society. As Miller (1998) claims, "animal rights advocates have not mounted major campaigns to protect individual bats, spiders, sharks or snakes from being killed, nor have they taken a strong stand that doing so is wrong" (p. 750). However, the issue is not simply confined to a hierarchy based on animal complexity, as was made clear in the results of this study, in which the most complex deserve greater moral consideration. As Neversand Gebhard (1997) verified, children older than ten would not hesitate to subordinate their interests to those of an animal, particularly if it was a pet. But, the same would not happen if the interests of a domestic pig were at stake. And, as Melson (2001) states, cultural images transmitted about animals are deeply contradictory: to fish and hunt are prized, familiar practices, but to attack wandering cats is considered barbarian; thousands of animals die in slaughter houses 
but the slaughtering should not be appreciated or the suffering prolonged; some species are served as food in certain places and venerated in others.

This study raises the issue of what the incidence of biocentric thinking would be if, in the case of the codfish dilemma, seals were replaced by another animal capable of generating less empathy in children, like, for instance, sharks? And if in the hypothetical dilemma, we instead used a more dangerous animal such as a wolf, for example?

It is important to bear in mind that the answers given by the children revealed anthropomorphic thinking in several situations by conferring supposedly human capacities on non-human animals. Serpell (1996) claims that the tendency to anthropomorphize animals does not necessarily lead to consideration of their interests. For instance, some predators can be judged as dangerous or brutal solely on the basis of their natural characteristics. Nevertheless, the processes of anthropomorphization also favour processes of identification with other animals. As Myers et al. (2003) says, these processes should be envisaged as seeds of mature forms of valuing other animals, species and systems and not as ways that detract from ecological understanding.

Consequently, the findings from this study may be important for parents and particularly primary schools in selecting broader types of places where it is possible for students to observe animals in their free time or as part of their outdoor activities.

The results from the present study could be of great relevance both for parents and particularly, $1^{\text {st }}$ cycle teachers. The potential for child contact with a wider number of places where they can interact with animals can unquestionably perform an important role in the development of a more effective understanding of the needs of other living creatures and the factors that contribute more to their well being. This form of contact maybe can help to reduce some of the forms of anthropomorphic thinking so commonly 
seen in children. Therefore the importance of the children's contact with different places, from controlled environments depending ongoing human management to those of a less human intervention nature in the incidence of non-anthropocentric reasoning should be studied.

From an educational point of view, the capacity of children to think in a nonanthropocentric way can be fostered through the selection of issues and activities that also lead to the perception of the conditions that favour the welfare of other living creatures and to a progressive perception of the multiple biotic and abiotic interactions occurring in nature. It can allow a better exploration of controversial issues in the curriculum, some of them linked to science education, like the use of animals in circuses, the use of animals in science, the introduction of living beings into ecosystems, the trade in exotic animals, the cultural performances involving animals or simple hunting. Of course, the choice of the issues can never lose sight of the subject suitability, nor the adoption of approaches geared to the age of the pupils taken not in a deterministic way but as a factor which, linked to psychological development, can affect the comprehension of certain arguments. Moreover when some children think in a nonanthropocentric way, the issues debates can expose other children to arguments that they never considered before.

To conclude, it should be said that there is nothing intrinsically wrong with anthropocentric reasoning, since it is used by children and adults in many situations. However, it is difficult to disagree with Rolston III (1994) when he states, "An admirable trait in persons is their capacity to appreciate things outside themselves, things that have no economic, medical or industrial uses, perhaps even no ordinary recreational, aesthetic or scientific value" (p.163). This is why non-human centred reasoning is so important. 
Acknowledgements

The authors acknowledges Adrienne Loffredo of /Center of Research, Teaching \& Learning/from Wake Forest University, School of Medicine of Wiston-Salem, North Carolina, United States.

\section{References}

Callicott, J. B. (1989). In Defense of The Land Ethic. Essays in Environmental Philosophy. New York: State University of New York Press.

Conover, W. J. (1999). Practical Nonparametric Statistics ( $3^{\mathrm{a}}$ ed.). New York: John Wiley and Sons, Inc.

Dunlap, R., K, Van Liere, K., Mertig, A. \& Jones, R. (2000).Measuring Endorsement of the New Ecological Paradigm: A Revised NEP Scale. Journal of Social Issues, $56(3), 425-442$.

Franklin, A. (2008). Animals \& modern cultures. London: Sage Publications Inc.

Kahn, P. H., Jr, (1997). Children's Moral and Ecological Reasoning About the Prince William Sound Oil Spill. Developmental Psychology, 33 (6), 1091-1096.

Kahn, P. H., Jr. (1999). The Human Relationship with Nature. Development and Culture. Cambridge, Massachusetts: The MIT Press.

Kahn, P. H., Jr. (2002). Children's Affiliations with Nature: Structure, Development, and the Problem of Environmental Generational Amnesia. In P. H. Kahn e S. R. Kellert (Eds.). Children and Nature (pp. 93-116). Cambridge, Massachusetts: The MIT Press.

Kahn, P. H., Jr. \& Lourenço, O. (2002). Water, air, fire, and earth: A developmental study in Portugal of environmental moral reasoning. Environment and Behaviour, 34, 405-430.

Kellert, S. R. (1997). Kinship to Mastery. Biophilia in Human Evolution and Development. Washington: Island Press. 
Kellert, S. R. (2005). Building for life. Designing and understanding the human-nature connection. Washington: Island Press.

Kohlberg, L. (1981). The Philosophy of Moral Development: Essays on Moral Development (Volume one). New York: Harper \& Row.

Kortenkamp, V. K. \& Moore, C. F. (2009). Children's Moral Evaluations of Ecological Damage: The Effect of Biocentric and Anthropocentric Intentions. Journal of Applied Social Psychology, 39 (8), 1785-1806.

Kurlansky, M. (1999). Cod: A Biography of the Fish that Changed the World. London: Vintage Books.

Lijmbach, S., Margadant-Van Archen, M., Van Koppen, C. S. A. \& Wals, A. (2002). 'Your View of Nature is Not Mine': learning about pluralism in the classroom. Environmental Education Research, 8 (2), 121-135.

Lima, A. V. e Guerra, J. (2004). Degradação Ambiental, Representações e Novos Valores Ecológicos. In J. F. Almeida (Org.). Os Portugueses e o Ambiente. II Inquérito Nacional às Representações e Práticas dos Portugueses sobre o Ambiente (pp. 7-64). Oeiras: Celta Editora.

Littledyke, M. (2004). Primary children's views on science and environmental issues: examples of environmental cognitive and moral development. Environmental Education Research, 10 (2), 217-235.

Lourenço, O. (2006). Psicologia de Desenvolvimento Moral. Teoria, dados e implicações ( $3^{\mathrm{a}}$ ed.). Coimbra: Almedina.

Maple, T. (1995).Toward a responsible zoo agenda. In: B. Norton, M. Hutchins, E. Stevens \& T. Maple (Eds.). Ethics on the Ark: zoos, animal welfare, and wildlife (pp 20-30). Washington: Smithsonian Institution Press. 
Melson, G. F. (2001). Why the Wild Things Are. Animals in the Lives of Children. Cambridge, Massachusetts: Harvard University Press.

Miller, G.T. (1998). Living in the Environment (10 ${ }^{\mathrm{a}}$ ed.). Belmont (California): Wadsworth Publishing Company.

Myers, Jr., O. E. \& Saunders, C. D. (2002).Animals as Links toward Developing Caring Relationships with the Natural World. In P. H. Kahn e S. R. Kellert (Eds.). Children and Nature (pp. 153-178). Cambridge, Massachusetts: The MIT Press.

Myers, Jr., O. E., Saunders, C. D. \& Garrett, E. (2003). What do children think animals need? Aesthetic and Psycho-social Conceptions. Environmental Education Research, 9 (3), 305-325.

Myers, Jr., O. E., Saunders, C. D. \& Garrett, E. (2004). What do children think animals need? Developmental trends. Environmental Education Research, 10 (4), 545562.

Mortari, L. (2004). Educating to Care. Canadian Journal of Environmental Education, 9, 109-122.

Naess, A. (1989). Ecology, Community and Lifestyle. Cambridge: Cambridge University Press.

Nevers, P. \& Gebhard, U. (1997).Patterns of reasoning exhibited by children and adolescents in response to moral dilemmas involving plants, animals and ecosystems. Journal of Moral Education, 26 (2), 169-186.

Paul, E. S. (2005). Love of pets and love of people.In A. Podberscek, E. Paul \& J. Serpell (Eds.). Companion Animals and Us. Exploring the relationships between people and pets (pp. 168-186). Cambridge: Cambridge University Press. 
Piaget, J. (2001). The Psychology of Intelligence. London and New York: Routledge Classics. (Original work published 1947)

Regan, T. (1983). The case for Animal Rights. Berkeley, Los Angeles: University of California Press.

Rolston III, H. (1994). Conserving Natural Value. New York: Columbia University Press.

Seidman, I. (1998). Interviewing as Qualitative Research. A Guide for Researchers in Education and Social Sciences (2 ${ }^{\mathrm{a}}$ ed.). New York, London: Teachers College Press.

Serpell, J. (2005). Creatures of the unconscious: companion animals as mediators. In A. Podberscek, E. Paul \& J. Serpell (Eds.). Companion Animals and Us. Exploring the relationships between people and pets (pp. 108-121). Cambridge: Cambridge University Press.

Serpell, J. (1996). In the company of animals. Cambridge: Cambridge University Press. Severson \& Kahn (2010). In the orchard: Farm worker children's moral and environmental reasoning. Journal of Applied Social Psychology, 31, 249-256.

Singer, P. (1990). Animal liberation. London: Jonathan Cape.

Taylor, P. W. (1989). Respect for Nature. A Theory of Environmental Ethics.Princeton (New Jersey): Princeton University Press.

Vosniadou, S. (2007). The Cognitive-Situative Divide and the Problem of Conceptual Change, $42(1), 55-66$.

Vosniadou, S., Skopeliti, I. \& Ikospentaki, K. (2005). Reconsidering the role of artefacts in reasoning: Children's understanding of the globe as a model of the earth.Learning and Instruction, 15, 333-351. 
Wilson, R. (1993). The importance of environmental education at the early childhood level. Environmental Education and Information, 12 (1), 17-24. 
Table 1. Interview questions and their nature

\begin{tabular}{|c|c|c|}
\hline Number & Question & Nature of the question \\
\hline 1 & $\begin{array}{l}\text { Can you tell me some places where you have met } \\
\text { animals? } \\
\text { Where did you like to see them most? Why? } \\
\text { Do you think they were pleased in the places where } \\
\text { you saw them? }\end{array}$ & $\begin{array}{l}\text { Question about experiential aspects } \\
\text { of the child } \\
\text { Question about child's beliefs }\end{array}$ \\
\hline 2 & Do you have pets? & $\begin{array}{l}\text { Question about experiential aspects } \\
\text { of the child }\end{array}$ \\
\hline 3 & $\begin{array}{l}\text { Do you know a fish called codfish? Do you know } \\
\text { that this fish is decreasing in the oceans because its } \\
\text { fishing is increasing? Well, some scientists } \\
\text { discovered that seals also eat codfish. So, in Canada, } \\
\text { the authorities decided to kill a lot of seals to } \\
\text { prevent the continuous decreasing of this fish. Do } \\
\text { you think this was a right or a wrong decision? Why } \\
\text { was it a right decision? If this was not a right } \\
\text { decision, what other measure would you take? }\end{array}$ & $\begin{array}{l}\text { Ecological dilemma in relation to a } \\
\text { real scenario }\end{array}$ \\
\hline 4 & $\begin{array}{l}\text { A family went for a walk in a forest and found a } \\
\text { hedgehog. One of the members caught it and brought } \\
\text { it to their backyard. Do you think this was a right or } \\
\text { a wrong decision? Why?. }\end{array}$ & $\begin{array}{l}\text { Ecological dilemma in relation to a } \\
\text { hypothetical scenario }\end{array}$ \\
\hline 5 & $\begin{array}{l}\text { A family went for a walk in a forest and found a } \\
\text { young fox. One of the members caught it and } \\
\text { brought it to their backyard. Do you think this was a } \\
\text { right or a wrong decision? Why?. }\end{array}$ & $\begin{array}{l}\text { Ecological dilemma in relation to a } \\
\text { hypothetical scenario }\end{array}$ \\
\hline
\end{tabular}


Table 2. Places where children said they had seen animals and their preferences. Places where you have seen animals

\begin{tabular}{lcc}
\hline Urban spaces & $\mathbf{4 9}$ & $\mathbf{7}$ \\
\hline Urban and suburban green spaces & 38 & 7 \\
\hline Homes & 14 & - \\
\hline Shops & 1 & - \\
\hline Kennels & 1 & $\mathbf{1 0}$ \\
\hline Rural spaces & $\mathbf{2 5}$ & 10 \\
\hline Farms & 25 & $\mathbf{3 1}$ \\
\hline Thematic places with animals & $\mathbf{7 5}$ & 25 \\
\hline Zoos & 71 & 3 \\
\hline Badoka Park and the kind & 12 & 3 \\
\hline Oceanariums, aquariums and fluviariums & 11 & $\mathbf{1 5}$ \\
\hline Natural spaces & $\mathbf{3 7}$ & 13 \\
\hline Woods, forests, fields & 29 & - \\
\hline Beaches, sea coast & 5 & 2 \\
\hline Natural parks/ reference to such & 5 & $\mathbf{6 0}$ \\
\hline Non-codifiable answers & $\mathbf{2 1}$ & 4 \\
\hline Unsure answers/ vague places & 15 & 56 \\
\hline Absurd answers/does not know/does not answer & 6 & - \\
\hline
\end{tabular}

Where did you like to see them most? 
Table 3. Reasons given by children for preferring, liking or disliking the places they mentioned.

\begin{tabular}{lc}
\hline Anthropocentric reasons & $\mathbf{9 0}$ \\
\hline Because there were many animals / many unfamiliar animals (or the opposite) & 24 \\
\hline Because the animals were cute/ beautiful/ playful /sweet/ friendly & 32 \\
\hline Because I had direct contact with the animals or interacted with them (or the opposite) & 15 \\
\hline Because I saw my favourite animal there & 12 \\
\hline Because it was a new place for me & 2 \\
\hline Because I had more fun and there were animal shows & 2 \\
\hline Because I learned things about the animals & 3 \\
\hline Biocentric reasons & $\mathbf{2 7}$ \\
\hline Because they are free and/or in their habitat (or the opposite) & 18 \\
\hline Because they are well looked after & 1 \\
\hline Because it is possible to watch aspects of their behaviour & 8 \\
\hline Doesn't know & $\mathbf{1 7}$ \\
\hline
\end{tabular}


Table 4. Reasons given by children when evaluating if animals liked or not to be where they saw them.

\begin{tabular}{|c|c|c|c|}
\hline Reasons for liking & & Reasons for disliking or liking more or less & \\
\hline Anthropocentric reasons & 4 & Anthropocentric reasons & - \\
\hline -They like to show off to humans & 4 & & \\
\hline Biocentric reasons & 84 & Biocentric reasons & 52 \\
\hline Favourable conditions for their development & & Unfavourable conditions for their development & \\
\hline $\begin{array}{l}\text {-They had space/ food/ were well looked } \\
\text { after }\end{array}$ & 42 & -They had little space/ no food/ were abandoned & 7 \\
\hline -They were in their habitat & 9 & -They had unfavourable abiotic conditions & 1 \\
\hline -They like to be free & 8 & -They were imprisoned/ should be free & 41 \\
\hline Manifestations of welfare & & Manifestations of lack of welfare & \\
\hline -They were having a good time & 24 & -They are scared by people & 1 \\
\hline -They were protected against extinction & 1 & -Hunters/Fishermen kill them & 2 \\
\hline Doesn't know/ doesn't answer & & & 4 \\
\hline
\end{tabular}


Table 5. Reasons for agreeing or disagreeing with the slaughter of seals, as described in the real dilemma presented.

\begin{tabular}{lllc}
\hline \multicolumn{1}{c}{ Agreement with the action } & \multicolumn{1}{c}{ Disagreement with action } \\
\hline Anthropocentric reasons & $\mathbf{2 0}$ & Anthropocentric reasons & $\mathbf{6}$ \\
\hline $\begin{array}{l}\text { So that cod does not disappear or decrease } \\
\text { in numbers and we can eat it }\end{array}$ & 19 & Seals are good and friendly and make shows & 3 \\
\hline $\begin{array}{l}\text { Only if they do not kill too many } \\
\text { (moderate anthropocentrism) }\end{array}$ & $\begin{array}{l}\text { There are no seals for children to watch or for } \\
\text { zoos }\end{array}$ & 2 \\
\hline & Because I like seals & 1 \\
\hline Biocentric reasons & $\mathbf{2}$ & Biocentric reasons & $\mathbf{1 0 1}$ \\
\hline To protect codfish and prevent extinction & 2 & $\begin{array}{l}\text { Seals need to eat/ have the right to eat/ we } \\
\text { shouldn't think only about ourselves }\end{array}$ & 22 \\
& & $\begin{array}{l}\text { Seals are living animals and also deserve to } \\
\text { live/ animals shouldn't be killed }\end{array}$ & 65 \\
\hline & Seals are/ will be on the verge of extinction & 14 \\
\hline & Ecocentric reasons & $\mathbf{1 0}$ \\
\hline & Seals should live in peace and harmony & 2 \\
\hline & Seals are an element from nature & 5 \\
\hline & Seals are essential to the sea & 2 \\
\hline & Nature works like that & 1 \\
\hline
\end{tabular}


Table 6. Alternative solutions to the slaughtering of seals suggested by children.

\begin{tabular}{lc}
\hline Anthropocentric solutions & $\mathbf{3 9}$ \\
\hline To separate seals from fish/ put them in a different place & 33 \\
\hline To make them familiar with fish & 5 \\
\hline To fish the cod before the seals do it & $\mathbf{3 3}$ \\
\hline Biocentric solutions & 10 \\
\hline We should eat other kinds of fish & 11 \\
\hline To fish less/ to eat less & 2 \\
\hline To fish where there are no seals & 10 \\
\hline To share with seals (conciliating) & 2 \\
\hline To increase codfish reproduction (conciliating) & $\mathbf{4 8}$ \\
\hline Doesn't know/ never thought about it & \\
\hline
\end{tabular}


Table 7. Reasons for agreeing or disagreeing with the action of capturing a hedgehog and a young fox and putting them in a backyard in an urban environment.

\begin{tabular}{|c|c|c|c|c|c|}
\hline $\begin{array}{c}\text { Agreement with the } \\
\text { action }\end{array}$ & hedgehog & $\begin{array}{c}\text { young } \\
\text { fox }\end{array}$ & $\begin{array}{c}\text { Disagreement with the } \\
\text { Action }\end{array}$ & hedgehog & $\begin{array}{c}\text { young } \\
\text { fox }\end{array}$ \\
\hline \multirow[t]{4}{*}{ Anthropocentric reasons } & - & - & Anthropocentric reasons & 13 & 25 \\
\hline & & & It can prick people & 11 & \\
\hline & & & $\begin{array}{l}\text { It can transmit diseases and } \\
\text { cause allergies }\end{array}$ & 2 & \\
\hline & & & $\begin{array}{l}\text { It can attack people and ruin } \\
\text { things }\end{array}$ & - & 25 \\
\hline Biocentric reasons & 17 & 15 & Biocentric reasons & 101 & 98 \\
\hline $\begin{array}{l}\text { The backyard offers } \\
\text { conditions (space and food) } \\
\text { for looking after the animal } \\
\text { properly }\end{array}$ & 6 & & The animal wants to be free & 20 & 9 \\
\hline To take care of the animal & 2 & 8 & $\begin{array}{l}\text { Those are wild animals that } \\
\text { live in the woods }\end{array}$ & 60 & 29 \\
\hline $\begin{array}{l}\text { Difficulty of adaptation to } \\
\text { the woods of a young } \\
\text { animal }\end{array}$ & 1 & & $\begin{array}{l}\text { It is kept apart from its family/ } \\
\text { it should stay with its mother }\end{array}$ & 12 & 50 \\
\hline $\begin{array}{l}\text { The backyard is safer than } \\
\text { the woods/ protection from } \\
\text { predators }\end{array}$ & 5 & 5 & The backyard is not suitable & 2 & 4 \\
\hline The animal would like it & 2 & 1 & $\begin{array}{l}\text { They don't know what they eat } \\
\text { / how to feed them }\end{array}$ & 5 & 5 \\
\hline \multirow[t]{2}{*}{ One should ask the animal } & 1 & 1 & They could hurt it & 1 & \\
\hline & & & $\begin{array}{l}\text { They wouldn't be able to look } \\
\text { after it when on holiday }\end{array}$ & 1 & \\
\hline Impossible to codify & & & & & \\
\hline $\begin{array}{l}\text { It would look nice in the } \\
\text { backyard }\end{array}$ & 1 & & & & \\
\hline $\begin{array}{l}\text { It eats animals on the verge } \\
\text { of extinction }\end{array}$ & & 1 & & & \\
\hline
\end{tabular}


Table 8. Level of significance obtained after the application of the chi-squared test $(\chi 2)$ to each of the questions able to generate anthropocentric and non-anthropocentric thinking according to the independent variables gender, school year of the children, contact with animals and school origin. (ns -not significant)

\begin{tabular}{|c|c|c|c|c|c|c|}
\hline Questions & $\begin{array}{l}\text { Where did } \\
\text { you like to } \\
\text { see them } \\
\text { most? Why? }\end{array}$ & $\begin{array}{l}\text { Do you think } \\
\text { they were } \\
\text { pleased in } \\
\text { the places } \\
\text { where you } \\
\text { saw them? } \\
\text { Why? }\end{array}$ & $\begin{array}{l}\text { The } \\
\text { codfish } \\
\text { real } \\
\text { dilemma }\end{array}$ & $\begin{array}{l}\text { Alternative } \\
\text { solution to } \\
\text { the real } \\
\text { codfish } \\
\text { dilemma }\end{array}$ & $\begin{array}{l}\text { The } \\
\text { hedgehog } \\
\text { hypothetical } \\
\text { dilemma }\end{array}$ & $\begin{array}{l}\text { The young } \\
\text { fox } \\
\text { hypothetical } \\
\text { dilemma }\end{array}$ \\
\hline $\begin{array}{l}\text { School year } \\
\text { of the } \\
\text { children }\end{array}$ & $\mathrm{p}=0.041^{*}$ & ns & $\mathrm{p}=0.275$ & $\mathrm{p}=0.043^{*}$ & ns & $\mathrm{p}=0.827$ \\
\hline Gender & $p=0.101$ & ns & $p=0.473$ & $\mathrm{p}=0.962$ & ns & $p=0.134$ \\
\hline $\begin{array}{l}\text { Contact with } \\
\text { mammals }\end{array}$ & $\mathrm{p}=0.559$ & $\mathrm{p}=0.215$ & ns & $\mathrm{p}=0.460$ & ns & $\mathrm{p}=0.252$ \\
\hline \multirow[t]{2}{*}{$\begin{array}{l}\text { School of } \\
\text { origin }\end{array}$} & $\mathrm{p}=0.273$ & ns & ns & - & ns & $\mathrm{p}=0.962$ \\
\hline & \multicolumn{6}{|c|}{$\mathrm{p}<0.05^{*}$ (level of significance) } \\
\hline
\end{tabular}

